\title{
Niche complementarity between an alien predator and native omnivorous fish in the Wilge River, South Africa
}

\section{Reuhl J. Lombard ${ }^{1}$, Christian T. Chimimba ${ }^{2}$ and Tsungai A. Zengeya ${ }^{3^{*}}$}

${ }^{1}$ Department of Zoology and Entomology, University of Pretoria, Private Bag X20, Hatfield, 0028 South Africa ${ }^{2}$ Centre of Excellence for Invasion Biology, Department of Zoology and Entomology, University of Pretoria, South Africa, , University of Pretoria, Private Bag X20, Hatfield, 0028 South Africa

${ }^{3}$ Centre of Excellence for Invasion Biology, South African National Biodiversity Institute (SANBI), Kirstenbosch Research Centre, Claremont, South Africa

*Corresponding author, email: T.Zengeya@ $@$ sanbi.org.za

\section{Acknowledgments}

The DST-NRF Centre of Excellence for Invasion Biology is acknowledged for financial support. In addition, CTC and TZ also received further support from the South African National Research Foundation (NRF). We are also grateful to R. Marques, A. Kloppers, F. du Toit, J. Mulock-Houwer, N. Visser and Dr R. A. Lombard for their time and support in the field, and property owners who allowed us to work on their properties. Our appreciation also goes out to technical staff from the Department of Zoology and Entomology, University of Pretoria, with a special mention to Grant Hall from the Isotope Laboratory, Mammal Research Institute (MRI), University of Pretoria, Pretoria. 


\begin{abstract}
A major challenge in biological invasions is to predict community susceptibility to invasion. This study investigated trophic interrelationships between an alien predator, largemouth bass (Micropterus salmoides) and native omnivores sharptooth catfish (Clarias gariepinus) and largescale yellowfish (Labeobarbus marequensis) in an invaded aquatic system to elucidate factors that might have aided their successful establishment. It tested the hypothesis that $M$. salmoides is able to co-exist with the two native omnivores by either utilizing a previously vacant food niche or through niche complementarity. Gut content and stable isotope analyses were used to determine trophic interactions. There was no evidence that $M$. salmoides was utilizing a previously vacant food niche but instead it occupied a restricted and specialized niche within a broad niche space utilized by the native omnivores. Differences in niche space and size have resulted in minimal niche overlaps that imply niche complementarity. The introduction of M. salmoides raises concerns about increases in predation pressure in the system. This however, is difficult to ascertain because of complexities in measuring long-term trends in predator demands, abundance and community compensation mechanisms. There is a need for long-term monitoring of community structure, especially small-sized prey species that are vulnerable to increased predation pressure.
\end{abstract}

Keywords: Food resource partitioning, invasive species, stable isotopes, predation pressure 


\section{Introduction}

Alien predatory fish species have been introduced worldwide to enhance recreational and sport fishing (Cambray, 2003; Eby et al., 2006; Arlinghaus \& Cooke, 2009) and to boost fisheries (Pringle, 2005). Despite the positive socio-economic values derived from these introductions, these fish have also been implicated in adversely altering community structure and functioning in areas of introduction (Cambray, 2003; Cowx et al., 2010; Britton \& Orsi, 2012; Ellender \& Weyl, 2014). They affect communities through the replacement of native predators, competition for food and space, increased consumption of prey, prey extirpation, increased top-down control, alteration of food web structures, changes in habitat coupling as well as overall ecosystemlevel effects (see Eby et al., 2006 for a review of impacts of alien predatory fish).

Research on biological invasions has grown remarkably over the past few decades, yet predicting community susceptibility to invasion remains a major challenge (Sih et al., 2010). Two prominent concepts that have been put forward to explain the successful establishment of invasive species are the availability of vacant niches (Elton, 1958) or highly developed competitive abilities (Simberloff, 1982). The first concept suggests that introduced species utilize unexploited resources and this may facilitate successful establishment (e.g. Mack, 1996; Levine \& D’Antonio, 1999; Shea \& Chesson, 2002; Jackson \& Britton, 2014). The second tenet proposes that introduced species out-compete and displace native species for resources such as habitat, food and breeding space (e.g., Blanchet et al., 2007; Zengeya \& Marshall, 2007; Bøhn et al., 2008; Hasegawa, 2016; TaabuMunyaho et al., 2016). The study of trophic resource partitioning in invaded aquatic systems can be a good way to characterize the long-term implications of non-native fish introductions and elucidate factors that might aid in their successful establishment (Vander Zanden et al., 2004; Gozlan et al., 2010; Sih et al., 2010; Britton et al., 2011; Juncos et al., 2015; Pereira et al., 2015; Comte et al., 2016).

This study therefore investigated trophic interrelationships between an alien predator fish, largemouth bass Micropterus salmoides (Lacepède, 1802) and two native facultative omnivores [sharptooth catfish, Clarias gariepinus (Burchell, 1822) and largescale yellowfish, Labeobarbus marequensis (Smith, 1841)] in the Wilge River, South Africa. It evaluated the hypothesis that M. salmoides was able to establish and is able to co-exist with the two native omnivores because it is either utilizing a previously vacant food niche or co-existence is achieved through patterns of minimal diet overlap. Micropterus salmoides is native to river systems in eastern North America from the Great Lakes to the Gulf Coast (Page \& Burr, 2011) but it has been widely introduced worldwide for sport fishing (Froese \& Pauly, 2016). The species was introduced into South Africa in 1928 (de Moor \& Bruton, 1988) and it has established in most river catchments throughout the country. Several factors 
might have contributed to its establishment and including 1) a sustained and wide spread stocking for sport fishing throughout the country, initially by government agencies and later by angling societies and private individuals, 2) availability of suitable receiving environments - the species has managed to colonise most upland systems which have a similar climate to its native range, and 3) highly developed aggressive feeding strategies M. salmoides is an aggressive predator that has had a major impact on small-sized native species in recipient systems (Ellender et al., 2011; Ellender \& Weyl, 2014; Ellender et al., 2014; Kimberg et al., 2014). It is largely piscivorous, but is also known to consume a variety of animal prey such as aquatic insects, frogs, crabs and small mammals (Weyl et al., 2010; Wasserman et al., 2011).

In most systems that M. salmoides has become established in South Africa, there is lack of a comparative top fish predator(s) and instead these systems are inhabited by facultative omnivores. This case is true for the Wilge River where before the introduction of M. salmoides, fish communities were likely controlled by large-sized omnivores (C. gariepinus and L. marequensis) as the top predators. These fish species consume a wide variety of prey (such as fish, insects, snails, clams, crabs, algae and macrophytes) and their diet varies in relation to food availability, different environments, season and the presence or absence of competing fish species and predators (Skelton, 2001; Marshall, 2011). The broad and versatile food niche among the two omnivores is likely to lead to low food resource overlap with M. salmoides. This study was therefore designed to assess whether M. salmoides is able to co-exist with the native omnivore species because it is either utilizing a vacant niche or through niche complementarity. The euryphagous feeding pattern of native omnivorous species versus the more stenophagous nature of $M$. salmoides may minimise niche overlaps and allows for coexistence. In addition, a euryphagous feeding strategy may allow for the native omnivore species to shift resources and ultimately alter their trophic position in response to fluctuations in resource availability and/or potential competition for food with $M$. salmoides. 


\section{Materials and Methods}

Study sites and sampling

Study sites were located on the Wilge River, a major perennial tributary of the Olifants River, which originates in the Highveld grasslands of the Mpumalanga and Gauteng Provinces in South Africa (Fig. 1). The catchment area of the Wilge River is about $4400 \mathrm{~km}^{2}$ and the area receives summer rainfall with mean annual precipitation of $670 \mathrm{~mm}$ (Schulze et al., 1997; Schultz \& Watson, 2002). The vegetation ranges from Highveld grasslands in the upper reaches of the catchment to sub-tropical woodland eco-region in the lower reaches (Mucina \& Rutherford, 2006). The river flows through the Waterberg quartzite and conglomerate geological formation where it has incised a deep narrow valley and the river profile is characterised by a series of staggered rapids and runs that are interspersed by deeper and wider pools (EMF, 2009). Fish were sampled at six sites (Fig. 1) between October 2013 and September 2014 during periods of high flow (October - March) and low flow (June - September) using a variety of sampling techniques. Shallow reaches $(<1.35 \mathrm{~m})$ were sampled using an electrofisher (Samus Special Electronics, Warsaw, Poland) while large and deep channels were sampled using three fleets of gill nets as well as angling.

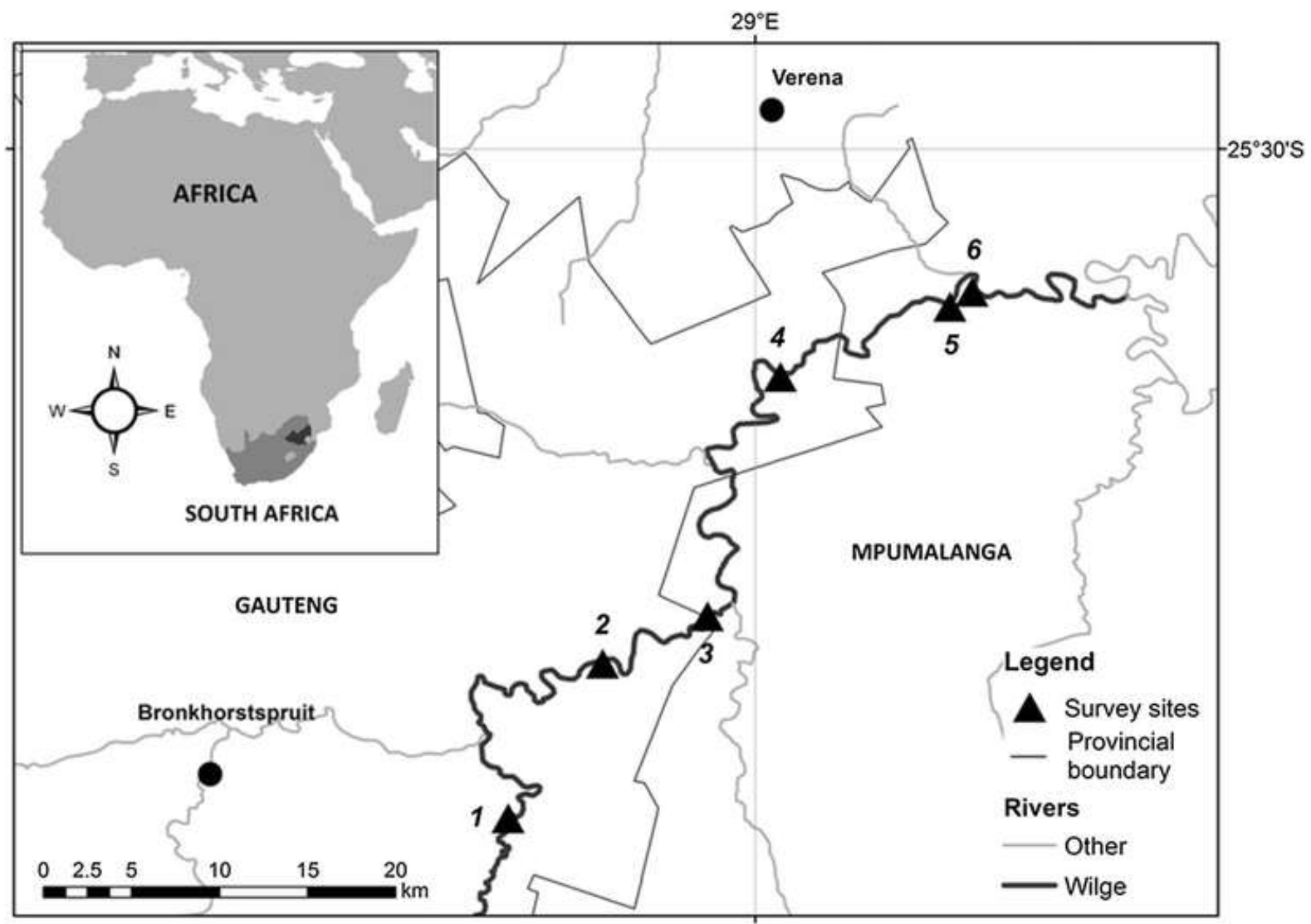

Fig. 1. The location of sampling sites along the Wilge River, South Africa. The sampled river reach was $77 \mathrm{~km}$ in length and stretched from the east of Bronkhorstspruit to the southeast of Verena. Sites are numbered in a downstream direction ( 1 = upper reaches, $6=$ lower reaches $)$ 
The fish fauna in the Wilge River system is composed of 20 fish species, four of which are alien [common carp Cyprinus carpio Linnaeus, 1758; mosquito fish Gambusia affinis (Baird \& Girard, 1853); small mouth yellowfish Labeobarbus aeneus (Burchell, 1822) and M. salmoides] (Table 1). Preliminary food web analysis showed that only two species (C. gariepinus and L. marequensis) had potential trophic overlap with $M$. salmoides. Therefore, for brevity, the other 17 species were excluded from the analysis. To account for spatial and temporal variability in isotopic values among the six sampling sites, diet comparisons were restricted to samples collected from 1) the same season 2) sites where M. salmoides was sampled and 3) sites where the isotope signatures for each of the three fish species were not statistical different. Three sites (site $1,4,6)$ met these criteria. In addition, the analysis was restricted to samples collected during high flow because low flow samples were depauperate for any conclusive analysis.

Table 1. The mean trophic positions (with standard deviations in brackets) of fish species found in the Wilge River system, South Africa. Data from Kleynhans et al. (2007), Deacon \& Kotze (2009), Rashleigh et al. (2009) and this study. Alien species are indicated in bold and species with an asterisk were not sampled and their trophic levels were obtained from the literature (Froese \& Pauly 2016).

\begin{tabular}{|c|c|c|}
\hline Trophic positon & Trophic level & Species \\
\hline \multirow[b]{2}{*}{ Top predators } & $4.3(0.3)$ & Micropterus salmoides \\
\hline & $4.2(1.2)$ & Labeobarbus marequensis \\
\hline \multirow{10}{*}{ Mid-level predators and omnivores } & $3.9(0.4)$ & Clarias gariepinus \\
\hline & $3.7(0.2)$ & Amphilius uranoscopus \\
\hline & $3.6(0.1)$ & Enteromius neefi \\
\hline & $3.6(0.1)$ & Chiloglanis pretoriae \\
\hline & $3.4(0.6)$ & Labeobarbus polylepis \\
\hline & $3.1(0.4)$ & Labeobarbus aeneus* \\
\hline & $3.1(0.2)$ & Gambusia affinis* \\
\hline & $3.1(0.0)$ & Cyprinus carpio* \\
\hline & $3.1(0.2)$ & Pseudocrenilabrus philander \\
\hline & $3.0(0.2)$ & Enteromius anoplus \\
\hline \multirow{8}{*}{ Omnivores, herbivores and detritivores } & $2.9(0.3)$ & Marcusenius macrolepidotus \\
\hline & $2.9(0.2)$ & Enteromius unitaeniatus \\
\hline & $2.9(0.1)$ & Mesobola brevianalis \\
\hline & $2.8(0.4)$ & Labeo umbratus* \\
\hline & $2.8(0.1)$ & Tilapia sparrmanii \\
\hline & $2.6(0.1)$ & Enteromius trimaculatus \\
\hline & $2.5(0.1)$ & Enteromius paludinosus \\
\hline & $2.4(0.2)$ & Labeo rosae* \\
\hline
\end{tabular}




\section{Determination of diet and trophic interactions}

Gut content (GC) and stable isotope (SI) analyses were used to determine diet and trophic interactions between M. salmoides and native fish species in the Wilge River. These two complimentary methods are increasingly being used concurrently to characterize changes in the structure and flow of energy in aquatic food webs related to non-native fish introductions (Zengeya et al., 2011; Kadye \& Booth, 2012). Using both methods allows for a better estimate of the average diet for a fish as the two methods can reflect different times when the fish fed. Gut content analysis provides a snap shot of ingested food items within a short time frame (hours to days) while SI provides a longer time-averaged estimate (days to months) of food assimilated by a fish (Gearing, 1991). Subtle patterns of niche complementarity are not always apparent when the two methods are used in isolation (e.g. see Zengeya et al. 2011). Gut content analysis is constrained by difficulties in quantifying and identifying food items, differential digestive rates of ingested material, not all digested material is assimilated and large samples sizes over a long time period are required in-order to give an accurate estimation of niche breadth (Hyslop, 1980). In-turn, stable isotope analysis also has limitations to its application such as variations in species-specific nitrogen isotope fractionation according to food source and dietary nitrogen content, while carbon isotope ratios are dependent on metabolic pathways, season and geographical regions (Vanderklift \& Ponsard, 2003; Fry, 2006; Finlay \& Kendall, 2007; Marshall et al., 2007). Therefore in this study, gut content analysis was used to identify possible food items and the observed food matrix was then used to calibrate the stable isotope mixing models. Stable isotope data were then used to differentiate food niches among fish species in terms of space, size and degree of overlap.

\section{Stomach content analysis}

Stomach contents were analysed using the modified methods of Platter \& Potter (2001) and Zengeya \& Marshall (2007). In brief, individual stomach contents were suspended in $100 \mathrm{ml}$ of water and examined under a microscope. The contribution of each food category in each gut was estimated by evenly spreading all contents from each gut in a graduated petri dish and converting the surface area occupied by each ingested item to a percentage for each food category. Ingested items were identified to the lowest possible taxonomic level and then further pooled into broader taxonomic categories (such as sediments, detritus, algae, plant matter, zooplankton, macroinvertebrates, insects and fish) for quantitative estimates. 


\section{Stable isotope analysis}

The samples required to delineate the food web structure in the river system were collected from the environment based on food items that were identified in the gut contents. These included insects, tadpoles and crustaceans (i.e., freshwater crabs, clams and shrimps) that were collected using the kick-net method on all available substrates at each site. Terrestrial and aquatic plant material, detritus and algae were collected by hand while zooplankton was collected using a plankton drag net. Fish caudal muscle, plant and invertebrate samples were oven-dried at $70^{\circ} \mathrm{C}$ for 12 hours after which samples were ground to a fine powder using a mortar and pestle. Lipid extraction was done with 2:1 Chloroform-Ethanol until the solution reached a pre-determined state (Søreide et al., 2006). Inorganic carbons (i.e., $\mathrm{CaCO}_{3}$ ) were removed from all invertebrate and plant samples with 1 mol HCL (Søreide et al., 2006). Samples were then re-dried for 12 hours before aliquots of approximately 0.6 to $0.7 \mathrm{mg}$ ( 1 to $1.2 \mathrm{mg}$ for plant samples) were weighed into tin capsules that were precleaned in toluene. Isotopic analysis was done on a Flash EA 1112 Series coupled to a Delta V Plus stable light isotope ratio mass spectrometer via a ConFlo IV system (all equipment supplied by ThermoFischer, Bremen, Germany), housed at the Stable Isotope Laboratory, Mammal Research Institute (MRI), University of Pretoria, Pretoria, South Africa.

A laboratory running standard (Merck Gel: $\delta^{13} \mathrm{C}=-20.57 \%, \delta^{15} \mathrm{~N}=6.8 \%, \mathrm{C} \%=43.83, \mathrm{~N} \%=14.64$ ) and blank sample were run after every 12 samples. The standards were Vienna Pee Dee Belemnite limestone for $\delta 13 \mathrm{C}$ (Craig, 1957) and atmospheric nitrogen for $\delta 15 \mathrm{~N}$ (Ehleringer \& Rundel, 1989). Results were expressed in delta notation using a permil scale using the standard equation:

$$
\delta \mathrm{X}(\% \mathbf{0})=\left[\left(\mathrm{R}_{\text {sample }}-\mathrm{R}_{\text {standard }}\right) / \mathrm{R}_{\text {standard }}{ }^{-1}\right] \times 1000
$$

Where $\mathrm{X}={ }^{15} \mathrm{~N}$ or ${ }^{13} \mathrm{C}$ and R represents ${ }^{15} \mathrm{~N} /{ }^{14} \mathrm{~N}$ or ${ }^{13} \mathrm{C} /{ }^{12} \mathrm{C}$, respectively. Analytical precision was $<0.08 \%$ for $\delta^{13} \mathrm{C}$ and $<0.13 \%$ for $\delta^{15} \mathrm{~N}$.

\section{Statistical analysis}

A modified Costello method (Amundsen et al., 1996, modified from Costello, 1990) was used to calculate the contribution of each food item to the diet of each species. This index uses the frequency of occurrence and preyspecific abundance of each food item to give a two-dimensional representation of prey importance (dominant to rare) and feeding strategy (specialist to generalist). Frequency of occurrence (F\%) is expressed as percentage of the total number of investigated fish containing specific food item in that period and prey-specific abundance (A\%) is the sum of the stomach proportions that contained a particular prey type, divided by the total number of 
stomachs that contained the specific prey item. A one way analysis of similarly (ANOSIM) based on a BrayCurtis similarity matrix was then used to test for diet differences among species.

A Bayesian mixing model SIAR V4.0 for Stable Isotope Analysis in R (Parnell et al., 2010) was used to estimate the relative contributions of food sources to fish diet. The SIAR model was calibrated using food sources that were grouped into broader taxonomic categories based on a $k$-Nearest Neighbour analysis (Rosing et al., 1998); namely, seston, detritus, aquatic macrophytes, crustaceans, insects, molluscs and vertebrates. Raw fish isotopic values were corrected for trophic enrichment prior to analysis, using values calculated following the approach proposed by Hobson \& Welch (1992). In brief, trophic enrichment for a given food web can be estimated in cases where the diet of a particular consumer is well-known. In this study, we used the river sardine Mesobola brevianalis (Boulenger, 1908) and bulldog Marcusenius macrolepidotus (Peters, 1852) that were found to be insectivores in a parallel on-going study to calculate the step-wise enrichment of carbon and nitrogen from insects to fish muscle. The trophic enrichment factors obtained from the two species were further compared to other consumer-prey relationships within the food web to obtain a food web average of $3.39 \pm$ $0.08 \%$ for nitrogen and $0.1 \pm 0.1 \%$ for carbon. Concentration dependence (Phillips \& Koch, 2002) was also included into the model to take into account the different digestibility of food sources in the omnivorous diet of C. gariepinus and L. marequensis. The trophic structure of the fish fauna found in the river was determined using the equation:

$$
\mathrm{TP}=\left(\frac{\mathrm{N}_{\text {consumer }}-\mathrm{N}_{\text {baseline }}}{3.39}\right)+2
$$

Where 3.39 is the trophic enrichment factor and $\mathrm{N}_{\text {baseline }}$ was the $\delta 15 \mathrm{~N}$ of freshwater clams, a filter-feeding mollusc $\left(\delta^{13} \mathrm{C}=-28.23 \pm 1.88 \%\right.$ o, $\delta 15 \mathrm{~N}=10.70 \pm 0.64 \%$ ). Nonparametric Kruskal-Wallis, followed by a MannWhitney pairwise post-hoc tests (Zar, 1996) were used to test for differences in the mean stable isotope ratios for $\delta 15 \mathrm{~N}$ and $\delta 13 \mathrm{C}$ among fish species because isotopic data departed from normality and homogeneity of variance.

Sample size corrected standard ellipse areas (SEAc) in the R package Stable Isotope Ellipses in $R$ (SIBER) (Jackson et al., 2011) were used to estimate niche size and trophic overlap among the three fish species. The niche space utilised by a species is often delineated by a convex hull drawn around the most extreme outliers in a given isotope bi-plot (Layman et al., 2007). This inherently makes it susceptible to changes in sample size, as a convex hull area is likely to increase with increasing sample size. To counteract this sample size effect, Jackson et al. (2011) proposed the use of standard ellipse areas (SEA) which are constructed using 
variance and covariance of the isotope bi-plot to contain only $40 \%$ of the data, which represents the core isotopic niche that is not affected by sample size. The resultant SEA is then corrected to minimize bias caused by small sample sizes (SEAc) using the following correction factor:

$$
\mathrm{SEAc}=\operatorname{SEA} \times[(\mathrm{n}-1) /(\mathrm{n}-2)] .
$$

\section{Results}

Gut content

A total of 55 specimens of M. salmoides and the two native omnivores (L. marequensis and C. gariepinus) were collected for gut contents analysis (Fig. 2). The average proportion of empty stomachs among the three species was $21.4 \%$ but this varied considerably from low values in C. gariepinus (10\%) and M. salmoides (11.8\%) to $42.1 \%$ in L. marequensis. They were no significant differences in prey-specific abundance (Global $\mathrm{R}=0.12, \mathrm{P}>$ 0.05 ) but the frequency of food items among the three species was significantly different (Global $\mathrm{R}=0.15, P<$ 0.05). Pairwise comapsrions indicate that the significant difference $(P<0.05)$ was only between $M$. salmoides and C. gariepinus and not among any other species cross comparisons. Clarias gariepinus had a broad diet that consisted of various foods items such as detritus, algae, plant matter, zooplankton, insects, crustaceans (crabs, clams and shrimps) and vertebrates (frogs and fish) (Fig. 2). The most abundant (A = prey-specific abundance and $\mathrm{F}=$ frequency of occurrence $)$ food items were zooplankton $(\mathrm{A}=100 \%, \mathrm{~F}=7 \%)$, algae $(\mathrm{A}=88 \%, \mathrm{~F}=6 \%)$ and plant materials $(A=67 \%, F=18 \%)$ but these were only observed in a few stomachs. Detritus $(A=65 \%, F$ $=42 \%)$ and insects $(\mathrm{A}=57 \%, \mathrm{~F}=59 \%)$ were relatively abundant and were frequently observed in most individuals. Crustacean $(\mathrm{A}=22 \%, \mathrm{~F}=24 \%)$ and vertebrate prey $(\mathrm{A}=26 \%, \mathrm{~F}=29 \%)$ were the least abundant and were only observed in a few stomachs.

Labeo marequensis also had a broad diet that consisted of detritus, algae, zooplankton, insects and crustaceans (Fig. 2). The most abundant foods were zooplankton $(\mathrm{A}=100 \%, \mathrm{~F}=9 \%)$ and crustaceans $(\mathrm{A}=$ $99 \%, \mathrm{~F}=9 \%)$ but these only occurred in few stomachs. Algae $(\mathrm{A}=45 \%, \mathrm{~F}=90 \%)$ and detritus $(\mathrm{A}=42 \%, \mathrm{~F}=$ $45 \%)$ were relatively abundant and occurred in most stomach while insects $(\mathrm{A}=11 \%, \mathrm{~F}=64 \%)$ were frequent but not abundant. In contrast, $M$. salmoides consumed only animal prey that consisted of insects $(\mathrm{A}=51 \%, \mathrm{~F}=$ $68 \%)$, crustaceans $(\mathrm{A}=63 \%, \mathrm{~F}=46 \%)$ and vertebrates $(\mathrm{A}=52 \%, \mathrm{~F}=69 \%)$ that were all abundant and occurred frequently in all the examined stomachs (Fig. 2). 


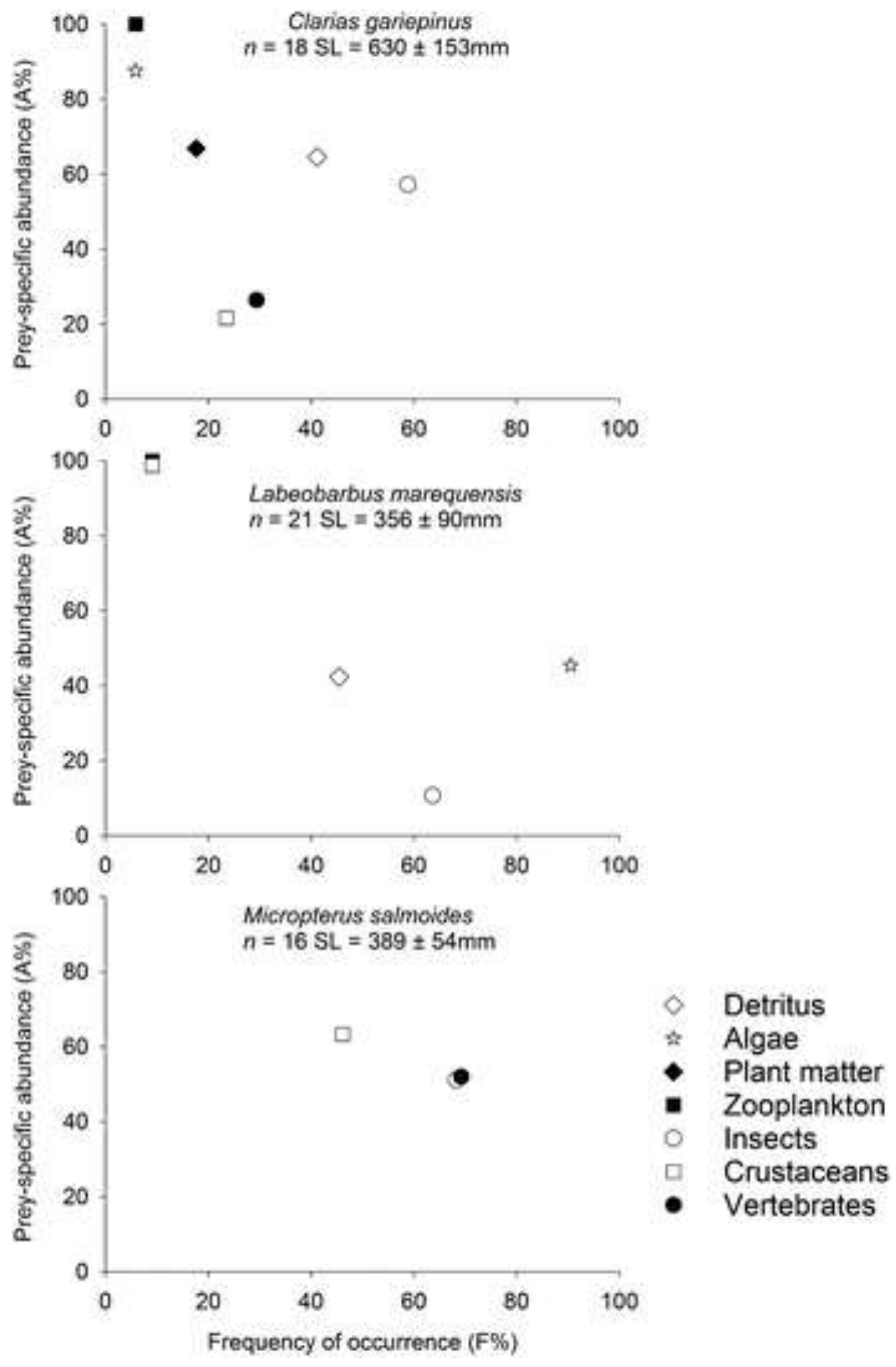

Fig. 2. The prey-specific abundances (A\%) and frequency of occurrence (F\%) of food items in the diet of two native omnivores (Labeobarbus marequensis and Clarias gariepinus) and the alien piscivore Micropterus salmoides in the Wilge River, South Africa. $n=$ sample size, $\mathrm{SL}=$ standard length \pm standard deviation

\section{Stable isotopes}

The results from the SIAR mixing model were similar with results from gut content analysis and indicated significant differences (Global $\mathrm{R}=0.12, P<0.05$ ) in diet of $M$. salmoides and $C$. gariepinus but not among any other species cross-comparisons. Clarias gariepinus was omnivorous with a broad diet composed of plant and animal prey while M. salmoides and L. marequensis were carnivorous and consumed largely crustaceans and vertebrates (Fig. 3). There were significant differences (Kruskal-Wallis $\chi 2=10.23$, df $=2, P<0.05$ ) in $\delta 15 \mathrm{~N}$ 


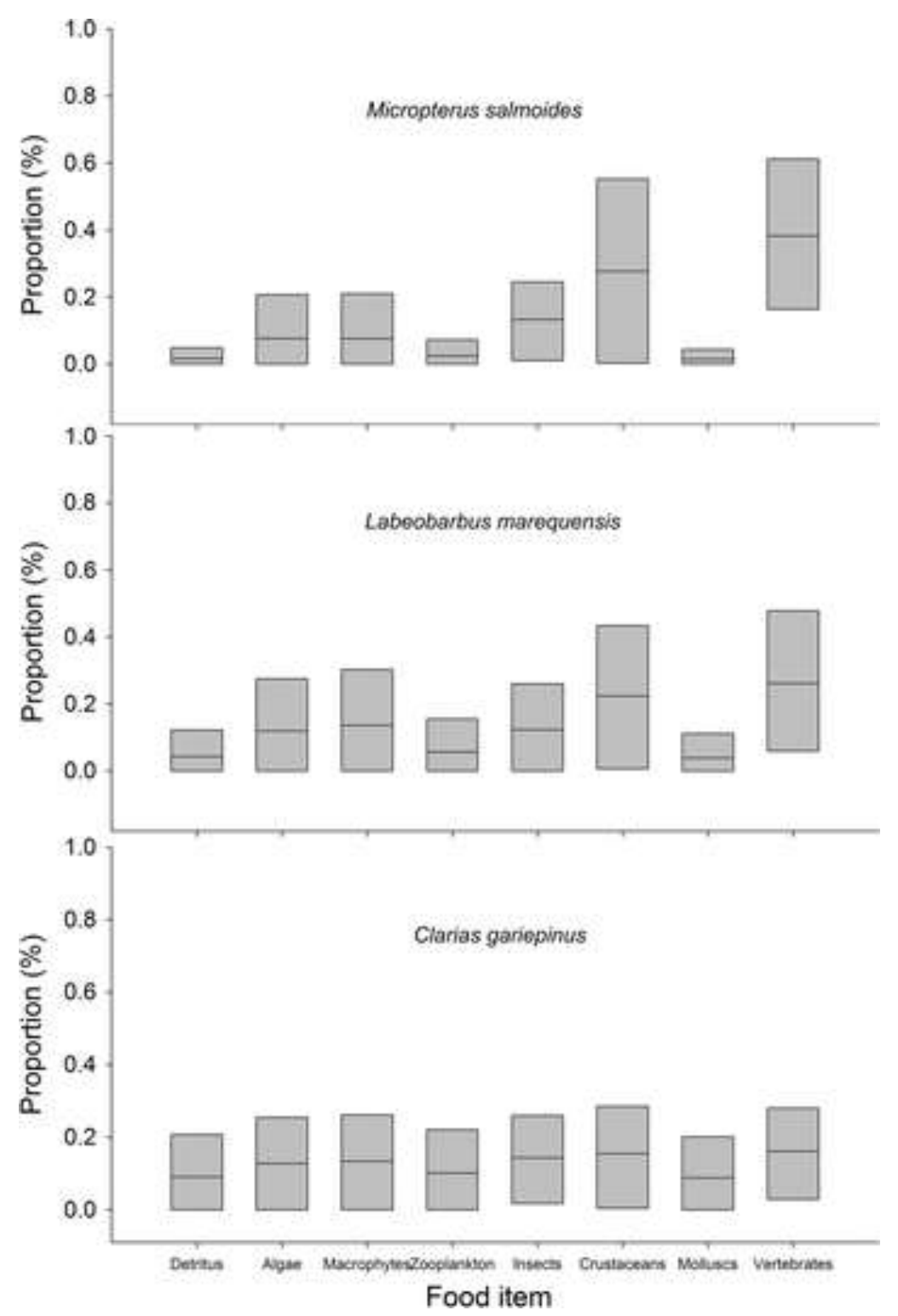

Fig. 3. The proportion (\% of isotopic value) of possible food sources utilised by two native omnivores (Labeobarbus marequensis and Clarias gariepinus) and the alien piscivore Micropterus salmoides from the Wilge River, South Africa. Boxes represent low and high 95\% confidence intervals around the median (solid line)

values among the three species (Fig. 4). Mann-Whitney post hoc tests indicated no significant differences in $\delta 15 \mathrm{~N}$ values between $C$. gariepinus $($ median $=16.92 \%)$ and L. marequensis $(15.47 \%)$ but the two species were significantly different $(P<0.05)$ from $M$. salmoides $(18.51 \%)$. In contrast, the median $\delta 13 \mathrm{C}$ values of $M$. salmoides (-21.59\%), L. marequensis $\left(-21.85 \%\right.$ ) and C. gariepinus $\left(-22.91 \%\right.$ ) were similar (Kruskal-Wallis $\chi^{2}$ $=5.09, \mathrm{df}=2, P>0.08)$ (Fig. 4). All three species showed no ontogenic changes in diet for $\delta 15 \mathrm{~N}[L$. marequensis $\left(\right.$ mean $\left.\mathrm{TL}=344.05 \pm 105.22 ; \mathrm{r}^{2}=0.01 ; P>0.05\right)$, C. gariepinus $\left(\right.$ mean $\mathrm{TL}=630.4 \pm 152.9 ; \mathrm{r}^{2}=$ $0.10 ; P>0.05$ ) and $M$. salmoides (mean $\left.\left.\mathrm{TL}=389.3 \pm 53.7 ; \mathrm{r}^{2}=0.01 ; P>0.05\right)\right]$ and for $\delta 13 \mathrm{C}[$ L. marequensis $\left(\mathrm{r}^{2}=0.01 ; P>0.05\right), C$. gariepinus $\left(\mathrm{r}^{2}=0.14 ; P>0.05\right)$ and $M$. salmoides $\left.\left(\mathrm{r}^{2}=0.05 ; P>0.05\right)\right]$. There were 
statistically significant differences (SIBER: $P<0.05$ ) in niche size (SEAc) among the three species. Labeobarbus marequensis had the largest niche (SEAc $=23.54)$, which was almost twice the size of $C$. gariepinus $(\mathrm{SEAc}=12.19)($ Fig. 5). In contrast, M. salmoides had the smallest niche size $(\mathrm{SEAc}=1.73)$. The most pronounced trophic overlap was between L. marequensis and C. gariepinus $(20.31 \%)$ while M. salmoides had a small overlap $(<7 \%)$ with any of the two native species.

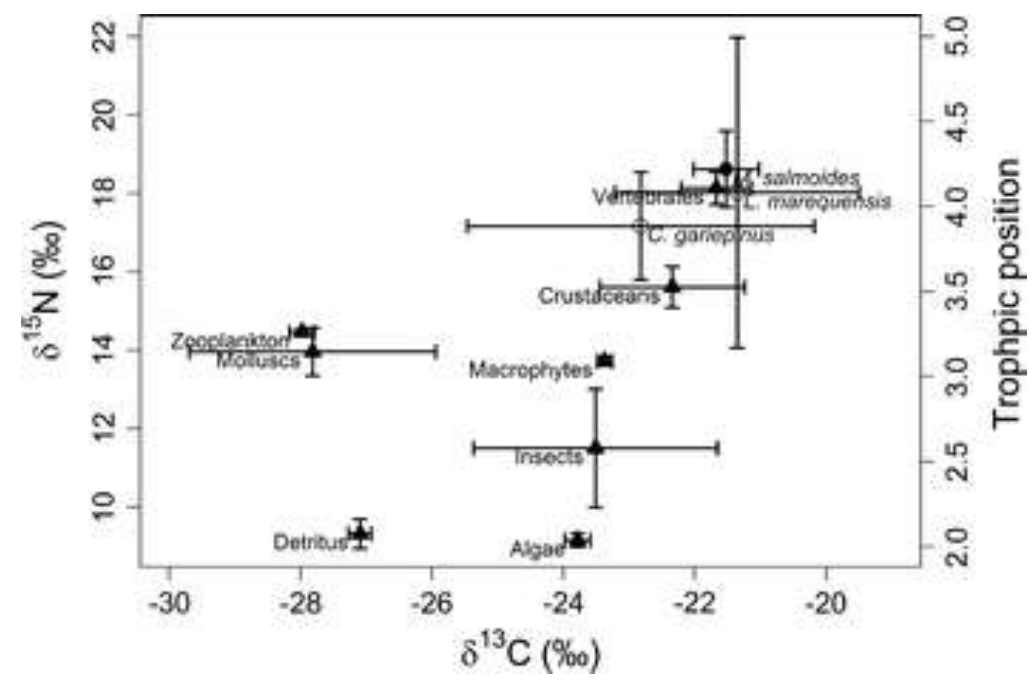

Fig. 4. Trophic positions, mean carbon $(\delta 13 \mathrm{C})$ and nitrogen $(\delta 15 \mathrm{C})$ values of two native omnivores (Labeobarbus marequensis and Clarias gariepinus) and the alien piscivore Micropterus salmoides in the Wilge River, South Africa. Error bars indicate standard deviations, $($ open circle $)=$ native species, $($ filled circle $)=$ introduced species and $($ filled triangle) $=$ possible food sources

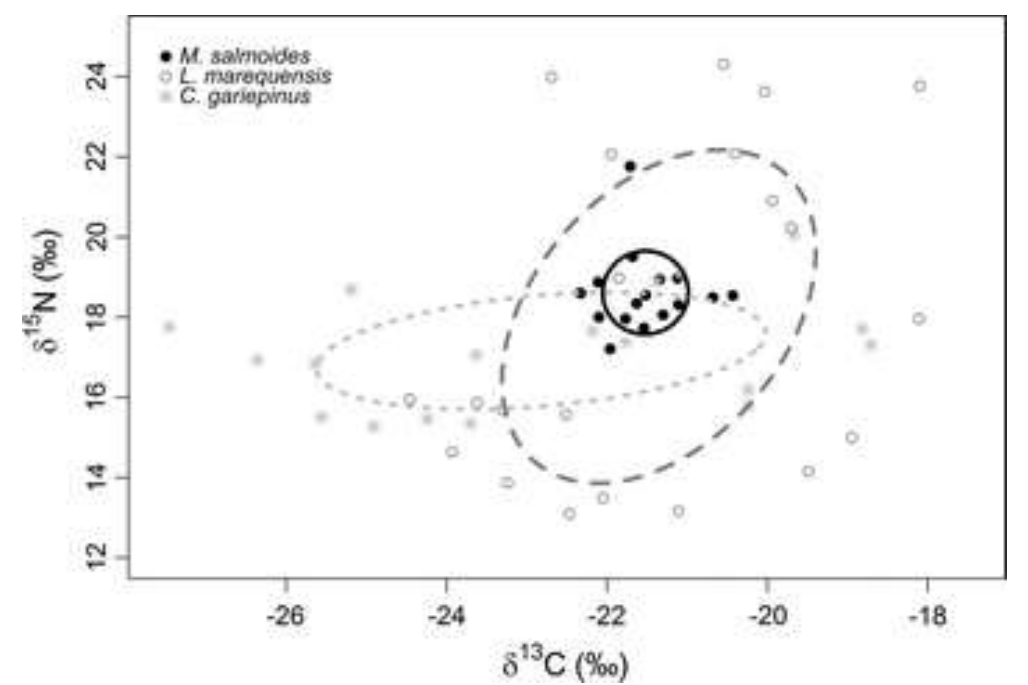

Fig. 5. Estimates of niche size and trophic overlap derived from size-corrected standard ellipse areas (SEAc) of two native omnivores Labeobarbus marequensis (dark grey lines) and Clarias gariepinus (light grey) and the alien piscivore Micropterus salmoides (black) from the Wilge River, South Africa

The trophic levels of all the 20 fish species that are known to occur in the system was composed of three categories: Top predators $(\mathrm{TP} \geq 4)$, mid-level predators and omnivores $(\mathrm{TP}=3-3.9)$ and herbivores and 
detritivores (TP < 3) (Table 1). Clarias gariepinus (3.9) was categorised as a mid-level predator and omnivore while L. marequensis (4.2) and M. salmoides (4.3) were top predators.

\section{Discussion}

This study assessed patterns of trophic partitioning between the alien piscivore $M$. salmoides and two native omnivore species in the Wilge River. We found no evidence that $M$. salmoides is utilizing a vacant food niche but instead it occupied a restricted and specialized niche within a broad niche space that is utilized by the native omnivore species. The differences in niche size and the minimal trophic overlap between the native omnivores and $M$. salmoides imply that niche complementarity may have been achieved through differences in prey preferences and feeding behaviour. In most invaded systems, alien and native species with similar niches coexist through niche differentiation along important niche axes such as diet or habitat (Goodenough, 2010; Schlaepfer et al., 2011). The niche space utilized by $M$. salmoides was entirely encompassed by that of $L$. marequensis, suggesting that the diet of L. marequensis entirely included that of $M$. salmoides, but was not limited to that of the latter. Labeobarbus marequensis is a facultative omnivore that feeds on a variety of food items that include detritus, algae, insects, crustaceans and small fish (Crass, 1964; Pienaar, 1978; Gaigher, 1979; Bell-Cross \& Minshull, 1988; Skelton, 2001; Fouché \& Gaigher, 2001; Fouché et al., 2003). This omnivorous feeding behaviour is well-supported by results from this study, where L. marequensis had the largest niche space of the studied species, inferring a broad-based diet. The large proportion of empty stomachs, enriched $\delta^{15} \mathrm{~N}$ values and a high trophic position imply that the diet of L. marequensis was dominated by animal prey and is similar to the diet of $M$. salmoides.

Similar to L. marequensis, C. gariepinus also had low niche overlaps with M. salmoides. Clarias gariepinus and M. salmoides are both aggressive and highly mobile predators that feed on a wide range of vertebrate species (Skelton, 2001; Garcia-Berthou, 2002; Post, 2003; Jang et al., 2006; Booth et al., 2010; Kadye \& Booth, 2012). However, the trophic overlap between the species is likely to be minimised by the generalist feeding behaviour of $C$. gariepinus and temporal difference in feeding behaviour. The large variation in $\delta^{13} \mathrm{C}$ and large niche size (SEAc) of $C$. gariepinus indicates a euryphagous diet consisting of a wide range of food sources in contrast to the smaller niche size of $M$. salmoides that suggests a stenophagous diet predominantly comprised of vertebrate prey. In addition, M. salmoides is a visual predator that utilizes daylight to hunt prey (Crowl, 1989; Petit, 2001), while C. gariepinus is predominantly a nocturnal feeder (Bruton, 1979; Hogendoorn, 1981; Viveen et al., 1985) that uses sensitive barbels to locate prey in murky environments. These temporal 
differences in hunting activity might also have implications on prey selection, where $M$. salmoides might be more selective while $C$. gariepinus might eat whatever is available.

The highlighted subtitle niche partitioning would likely reduce niche overlap especially as the three species have rather similar habitat affinities. The three species were caught in both fast-flowing (runs and rapids) and in slow flowing habitats such as deep pools. This is consistent with other comparative studies done elsewhere which consider the three species as eupotamonic (main stream) guild species (Gratwicke et al. 2003; Kimberg et al. 2014). However detailed telemetry studies are still required to investigate the home range and habitat use, the temporal distribution and population connectivity among the three species.

\section{Conservation implications}

The establishment of alien predators often leads to one of two outcomes: either the native predators are extirpated or native and alien species co-exist, thus increasing the species richness (Pringle, 2005; Eby et al., 2006; Kishe-Machumu et al., 2012; 2015). The introduction of M. salmoides, in conjunction with three other alien species has increased the number of omnivorous and predatory species by $40 \%$, raising concerns about the potential increase in predation pressure impacts. However, this difficult to ascertain because of complexities in measuring long-term trends in community absolute abundance, predator demands and community compensation mechanisms. However, the stenophagous diet of M. salmoides and its higher functional responses (resource uptake rate as a function of resource density) relative to the native predator species (Alexander et al., 2014), suggests an increased predation pressure to the system. Introduced predators that have higher functional responses relative to native predators tend to cause adverse ecological impacts in recipient systems (Bollache et al., 2008; Dick et al., 2013; Alexander et al., 2014). This assertion is supported by observed impacts of $M$. salmoides in other systems into which it has been introduced in southern Africa, where it has been implicated in the reduction in fish diversity and abundance of smaller-sized river minnows (Gratwicke \& Marshall 2001; Weyl et al., 2010; Ellender et al., 2011; Ellender et al., 2014; Kimberg et al., 2014). It is most likely that the impacts of M. salmoides will not manifest through the replacement of native predators/omnivores species but through increased consumption and extirpation of smaller-sized prey as observed elsewhere (Gratwicke \& Marshall 2001; Gratwicke et al. 2003; Ellender et al., 2014; Kimberg et al., 2014). However, a major limitation with these studies is that they have not quantified and compared the niche utilised by $M$. salmoides and the native omnivore species to assess whether it the former is utilising a vacant niche or co-existence is achieved through niche complementarity. This study therefore provides baseline evidence that co-existence in the Wilge 
River is achieved through niche complementarity. There is however a need for further studies in the river system to monitor long-term trends in community absolute abundance and resource partitioning (e.g., food and habitat) to have a better understanding of the overall impacts of $M$. salmoides on community structure and functioning in the Wilge River.

\section{References}

Alexander, M. E., J. T. A. Dick, O. L. F. Weyl, T. B. Robinson \& R. M. Richardson, 2014. Existing and emerging high impact invasive species are characterized by higher functional responses than natives. Biology Letters 10: 20130946.

Amundsen, P. A., H. M. Gabler \& F. J. Staldvik, 1996. A new approach to graphical analysis of feeding strategy from stomach contents data-modification of the Costello (1990) method. Journal of Fish Biology 48: 607-614.

Arlinghaus, R. \& S. J. Cooke, 2009. Recreational fisheries: socioeconomic importance, conservation issues and management challenges. In Dickson, B., J. Hutton \& W. A. Adams (eds), Recreational Hunting, Conservation and Rural Livelihoods: Science and Practice. Blackwell Publishing, Oxford: 39-58.

Bell-Cross, G. \& J. L. Minshull, 1988. The Fishes of Zimbabwe. National Museums and Monuments of Zimbabwe, Harare.

Blanchet, S., G. Loot, G. Grenouillet \& S. Brosse, 2007. Competitive interactions between native and exotic salmonids: a combined field and laboratory demonstration. Ecology of Freshwater Fish 16: 133-143.

Bøhn, T., P. Amundsen \& A. Sparrow, 2008. Competitive exclusion after invasion? Biological Invasions 10: 359-368.

Bollache, L., J. T. A. Dick, K. D. Farnsworth \& W. I. Montgomery, 2008. Comparison of the functional responses of invasive and native amphipods. Biological Letters 4: 166-169.

Booth, A. J., G. R. L. Traas \& O. L. F. Weyl, 2010. Adult African sharptooth catfish, Clarias gariepinus, population dynamics in a small invaded warm-temperate impoundment. African Zoology 45: 299-308.

Britton, J. R. \& M. L. Orsi, 2012. Non-native fish in aquaculture and sport fishing in Brazil: economic benefits versus risks to fish diversity in the upper River Paraná Basin. Reviews in Fish Biology and Fisheries 22: $555-565$.

Britton, J. R., R. E. Gozlan, \& G. H. Copp, 2011. Managing non-native fish in the environment. Fish and Fisheries 12: 256-274. 
Bruton, M. N., 1979. The role of diel inshore movements by Clarias gariepinus Pisces: Clariidae for the capture of fish prey. Transactions of the Zoological Society of London 35: 115-118.

Cambray, J. A., 2003. Impact of indigenous species biodiversity caused by the globalisation of alien recreational freshwater fisheries. Hydrobiologia 500: 217-230.

Comte, L., J. Cucherousset, S. Boulêtreau \& J. D. Olden, 2016. Resource partitioning and functional diversity of worldwide freshwater fish communities. Ecosphere 7(6):e01356. 10.1002/ecs2.1356.

Costello, M. J., 1990. Predator feeding strategy and prey importance: a new graphical analysis. Journal of Fish Biology 36: 261-263.

Cowx, I. G., R. Arlinghaus \& S. J. Cooke, 2010. Harmonizing recreational fisheries and conservation objectives for aquatic biodiversity in inland waters. Journal of Fish Biology 76: 2194-2215.

Craig, H., 1957. Isotopic standards for carbon and oxygen and correction factors for mass-spectrometric analysis of carbon dioxide. Geochimica et Cosmochimica Acta 12: 133-149.

Crass, R. S., 1964. Freshwater Fishes of Natal. Shuter \& Shooter, Pietermaritzburg.

Crowl, T. A., 1989. Effects of crayfish size, orientation, and movement on the reactive distance of largemouth bass foraging in clear and turbid water. Hydrobiologia 183: 133-140.

De Moor, I. J. \& M. N. Bruton, 1988. Atlas of alien and translocated indigenous aquatic animals of southern Africa. South African National Programmes Report 144: 128-146.

Deacon, A. R. \& P. J. Kotze, 2009. Ezemvelo-Telperion Nature Reserve: Aquatic biodiversity and baseline biomonitoring assessment - Year 1: 2008-2009.

Dick, J. T. A., K. Gallagher, S. Avlijas, H. C. Clarke, S. E. Lewis, S. Leung, D. Minchin, J. Caffrey, M. E. Alexander, C. Maguire, C. Harrod, N. Reid, N. R. Haddaway, K. D. Farnsworth, M. Penk and A. Ricciardi, 2013. Ecological impacts of an invasive predator explained and predicted by comparative functional responses. Biological Invasions 15: 837-845.

Eby, L. A., W. J. Roach, L. B. Crowder \& J. A. Stanford, 2006. Effects of stocking-up freshwater food webs. Trends in Ecology and Evolution 21: 576-584.

Ehleringer, J. R. \& P. W. Rundel, 1989. Stable isotopes: History, units and instrumentation. In Rundel, P. W., J. R. Ehleringer \& K. A. Nagy (eds), Stable Isotopes in Ecological Research. Springer-Verlag New York Inc.

Ellender, B. R. \& O. L. F. Weyl, 2014. A review of current knowledge, risk and ecological impacts associated with non-native freshwater fish introductions in South Africa. Aquatic Invasions 9: 117-132. 
Ellender, B. R., D.J. Woodford, O. L. F. Weyl, \& I. G. Cowx, 2014. Managing conflicts arising from fisheries enhancements based on non-native fishes in southern Africa. Journal of Fish Biology 85: 1890-1906.

Ellender, B. R., O. L. F. Weyl \& E. R. Swartz, 2011. Invasion of a headwater stream by non-native fishes in the Swartkops River system, South Africa. African Zoology 46: 39-46.

Elton, C. S., 1958. The Ecology of Invasions by Animals and Plants. Methuen, London.

Environmental Management Framework (EMF). 2009. Environmental Management Framework for the Olifants and Letaba River Catchment Areas: Draft Report on the Status Quo, Opportunities, Constraints and the Desired State, July 2009.

Finlay, J. C. \& C. Kendall, 2007. Stable isotope tracing of temporal and spatial variability in organic matter sources to freshwater ecosystems. In Michener, R. \& K. Lajtha (eds), Stable isotopes in ecology and environmental science $2^{\text {nd }}$ Edition. Blackwell Publishing, MA, USA.

Fouché, P. S. O. \& I. G. Gaigher, 2001. Niche differentiation in the rheophilic fishes of the Mutshindudi River. In Gaigher, I. G. (eds), A Socio-biological study of the aquatic resources and their utilisation in an underdeveloped rural region, the Mutshindudi River Catchment. WRC Project Report 714/3/01, Water Research Commission, Pretoria, 52-69.

Fouché, P. S. O., W. Vlok \& M. K. Angliss, 2003. The habitat preferences and food selection of Labeobarbus marequensis in the Luvuvhu and Mutale rivers. In Arderne, P (eds), Proceedings of the 7th Yellowfish Working Group Conference. Federation of Southern African Flyfishers, Johannesburg.

Froese, R. \& D. Pauly. Editors. 2016. FishBase. World Wide Web electronic publication. www.fishbase.org, version $(06 / 2016)$.

Fry, B., 2006. Stable Isotope Ecology. Springer, New York.

Gaigher, I. G., 1979. A synthesis of the feeding biology of indigenous South African freshwater fishes. Internal report of the Department of Cape Nature and Environmental Conservation, Stellenbosch, South Africa.

Garcia-Berthou, E., 2002. Ontogenetic diet shifts and interrupted piscivory in introduced largemouth bass (Micropterus salmoides). International Review of Hydrobiology 87: 353-363.

Gearing, J. N., 1991. The study of diet and trophic relationships through natural abundance of ${ }^{13} \mathrm{C}$. In Coleman, D. C. \& B. Fry (eds), Carbon isotope techniques. Academic Press, Inc. California.

Goodenough, A. E., 2010. Are the ecological impacts of alien species misrepresented? A review of the "native good, alien bad" philosophy. Community Ecology 11: 13-21. 
Gozlan, R. E., J. R. Britton, I. G. Cowx \& G. H. Copp, 2010. Current knowledge on non-native freshwater fish introductions. Journal of Fish Biology 44: 751-786.

Gratwicke, B. \& B. E. Marshall, 2001. The relationship between the exotic predators Micropterus salmoides and Serranochromis robustus and native stream fishes in Zimbabwe. Journal of Fish Biology 58: 68-75.

Gratwicke, B., B. E. Marshall \& T. Nhiwatiwa, 2003. The distribution and relative abundance of stream fishes in the upper Manyame River, Zimbabwe, in relation to land use, pollution and exotic predators. African Journal of Aquatic Science 28: 25-34.

Hasegawa, K., 2016. The density dependent interspecific competition between non-native salmonids, rainbow trout and brown trout. Environmental Biology of Fishes 99: 433-438.

Hobson, K. A. \& H. E. Welch, 1992. Determination of trophic relationships within a high Arctic marine food web using d13C and d15N analysis. Marine Ecology Progress Series 84: 9-18.

Hogendoorn, H., 1981. Controlled propagation of the African catfish, Clarias lazera (C. and V.) IV. Effect of feeding regime in fingerling culture. Aquaculture 24: 123-131.

Hyslop, E. J. 1980. Stomach contents analysis-a review of methods and their application. Journal of Fish Biology 17:411-429.

Jackson, A. L., R. Inger, A. C. Parnell \& S. Bearhop, 2011. Comparing isotopic niche widths among and within communities: SIBER - Stable Isotope Bayesian Ellipses in R. Journal of Animal Ecology 80: 595-602.

Jackson, M. C. \& J. R. Britton, 2014. Divergence in the trophic niche of sympatric freshwater invaders. Biological Invasions 16: 1095-1103.

Jang, M. H., G. J. Joo \& M. C. Lucas, 2006. Diet of introduced largemouth bass in Korean rivers and potential interactions with native fishes. Ecology of Freshwater Fish 15: 315-320.

Juncos, R., D. Milano, P. J. Macchi \& P. B. Vigliano, 2015. Niche segregation facilitates coexistence between native and introduced fishes in a deep Patagonian lake. Hydrobiologia 747: 53-67.

Kadye, W. T. \& A. J. Booth, 2012. Integrating stomach content and stable isotope analyses to elucidate the feeding habits of non-native sharptooth catfish Clarias gariepinus. Biological Invasions 14: 779-795.

Kimberg, P. K., D. J. Woodford, H. Roux \& O. L. F. Weyl, 2014. Species-specific impact of introduced largemouth bass Micropterus salmoides in the Groot Marico Freshwater Ecosystem Priority Area, South Africa. African Journal of Aquatic Science 39: 451-458. 
Kishe-Machumu M. A., F. Witte, J. H. Wanink \& E. F. B. Katunzi, 2012. The diet of Nile perch, Lates niloticus (L.) after resurgence of haplochromine cichlids in the Mwanza Gulf of Lake Victoria. Hydrobiologia 682: 111-119.

Kishe-Machumu, M. A., T. Voogd, J. H. Wanink \& F. Witte, 2015. Can differential resurgence of haplochromine trophic groups in Lake Victoria be explained by selective Nile perch, Lates niloticus (L.) predation? Environmental Biology of Fishes 98: 1255-1263.

Kleynhans, C. J., M. D. Louw \& J. Moolman, 2007. Reference frequency of occurrence of fish species in South Africa. Report produced for the Department of Water Affairs and Forestry (Resource Quality Services) and the Water Research Commission.

Layman, C.A., D.A. Arrington, G.C. Montana, \& D.M. Post, 2007. Can stable isotope ratios provide for community-wide measures of trophic structure. Ecology 88: 42-48.

Levine, J. M. \& C. M. D’Antonio, 1999. Elton revisited: a review of evidence linking diversity and invasibility. Oikos 87: 15-26.

Mack, R. N., 1996. Predicting the identity and fate of plant invaders: emergent and emerging approaches. Biological Conservation 78: 107-121.

Marshall, B. E., 2011. Fishes of Zimbabwe and their Biology. Smithiana Monograph 3. The South African Institute for Aquatic Biodiversity, Grahamstown: 290

Marshall, J. D., J. R. Brooks \& K. Lajtha, 2007. Sources of variation in the stable isotope composition of plants.

In Michener, R. \& K. Lajtha (eds), Stable isotopes in ecology and environmental science $2^{\text {nd }}$ Edition. Blackwell Publishing, MA, USA.

Mucina, L. \& M. C. Rutherfod, (eds) 2006. The vegetation of South Africa, Lesotho and Swaziland. Strelitzia 19. Pretoria, South Africa: South African National Biodiversity Institute (SANBI).

Page, L. M. \& B. M. Burr, 2011. Field Guide to Freshwater Fishes of North America North of Mexico. Peterson Field Guides series. Houghton Mifflin Harcourt, Boston, MA.

Parnell, A. C., R. Inger, S. Bearhop \& A. L. Jackson, 2010. Source partitioning using stable isotopes: Coping with too much variation. Plos ONE 5: e9672.

Pereira, L. S., A. A. Agostinho \& L. C. Gomes, 2015. Eating the competitor: a mechanism of invasion. Hydrobiologia 746: 223-231. 
Petit, G., 2001. Comportement, croissance et sécrétion hypophysaire de l'hormone de croissance chez le blackbass Micropterus salmö̈des en alternance jour/nuit ou en lumière continue. Phd Thesis, Université Jean Monnet, Saint-Étienne, France.

Phillips, D. L. \& P. L. Koch, 2002. Incorporating concentration dependence in stable isotope mixing models. Oecologia 130: 114-125.

Pienaar, U. De V., 1978. The Freshwater Fishes of the Kruger National Park. Sigma Press, Pretoria.

Platter, M. E. \& C. I. Potter, 2001. Partitioning of food resources amongst 18 abundant benthic carnivorous fish species in marine waters on the lower west coast of Australia. Journal of Marine Biology and Ecology 261: 31-54.

Post, D. M., 2003. Individual variation in the timing of ontogenetic niche shifts in largemouth bass. Ecology 84: 1298-1310.

Pringle, R. M., 2005. The origins of the Nile perch in Lake Victoria. Bioscience 55: 780-787.

Rashleigh, B., D. Hardwick \& D. Roux, 2009. Fish assemblage patterns as a tool to aid conservation in the Olifants River catchment (East). South Africa Water SA 35: 517-524.

Rosing, M. N., M. Ben-David \& R. P. Barry, 1998. Analysis of Stable Isotope Data: A K Nearest-neighbors Randomization Test. The Journal of Wildlife Management 62: 380-388.

Schlaepfer, M. A., D. F. Sax \& J. D. Olden, 2011. The potential conservation value of non-native species. Conservation Biology 25: 428-437.

Schultz, C. B. \& M. D. Watson, 2002. WSAM: Water Situation Assessment Model-Version 3: A decision support system for reconnaissance level planning. Volume 1: Theoretical Guide. Republic of South Africa: ARCUS-GIBB and DWAF.

Schulze, R. E., M. Maharaj, S. D. Lynch, B. J. Howe \& B. Melvil-Thomson, 1997. South African atlas for agrohydrology and climatology. University of Natal, Pietermaritzburg.

Shea, K., \& P. Chesson, 2002. Community ecology theory as a framework for biological invasions. Trends in Ecology and Evolution 17: 170-176.

Sih, A., D. I. Bolnick, B. Luttbeg, J. L. Orrock, S. D. Peacor, L. M. Pintor, E. Preisser, J. S. Rehage \& J. R. Vonesh, 2010. Predator-prey naïveté, antipredator behavior, and the ecology of predator invasions. Oikos 119: 610-621.

Simberloff, T. D., 1982. The status of competition theory in ecology. Annales Zoologici Fennici 19: 241-253. 
Skelton, P. H., 2001. A Complete Guide to the Freshwater Fishes of Southern Africa. Southern Book Publishers, Halfway House.

Søreide, J. E., T. Tamelander, H. Hop, K. A. Hobson \& I. Johansen, 2006. Sample preparation effects on stable $\mathrm{C}$ and $\mathrm{N}$ isotope values: a comparison of methods in Arctic marine food web studies. Marine Ecology Progress Series 328: 17-28.

Taabu-Munyaho, A., B. E. Marshall, T. Tomasson, \& G. Marteinsdottir, 2016. Nile perch and the transformation of Lake Victoria. African Journal of Aquatic Science 41: 127-142.

Vander Zanden, M. J., J. D. Olden, J. H. Thorne \& N. E. Mandrak, 2004. Predicting occurrences and impacts of smallmouth bass introductions in north temperate lakes. Ecological Applications 14: 132-148.

Vanderklift, M. A. \& S. Ponsard, 2003. Sources of variation in consumer-diet $\delta 15 \mathrm{~N}$ enrichment: a metaanalysis. Oecologia 136: 169-182.

Viveen, W. J. A. R., C. J. J. Richter, P. G. W. J. Van Oordt, J. A. L. Janseen \& E. A. Huisman,1985. Practical manual for the culture of the African catfish Clarias gariepinus. Pudoc, The Hague, Netherlands: 94.

Wasserman, R. J., N. A. Strydom \& O. L. F. Weyl, 2011. Diet of largemouth bass, Micropterus salmoides (Centrarchidae), an invasive alien in the lower reaches of an Eastern Cape river, South Africa. African Zoology 46: 378-386.

Weyl, P. S., F. C. De Moor, M. P. Hill \& O. L. F. Weyl, 2010. The effect of largemouth bass Micropterus salmoides on aquatic macro-invertebrate communities in the Wit River, Eastern Cape, South Africa. African Journal of Aquatic Science 35: 273-281.

Zar, J.H., 1996. Biostatistical analysis. 3rd ed. Prentice Hall, New Jersey.

Zengeya, T. A. \& B. E. Marshall, 2007. Trophic interrelationships amongst cichlid fishes in a tropical African reservoir (Lake Chivero, Zimbabwe). Hydrobiologia 592: 175-182.

Zengeya, T. A., A. J. Booth, A. D. S. Bastos \& C. T. Chimimba, 2011. Trophic interrelationships between the exotic Nile tilapia, Oreochromis niloticus and indigenous tilapiine cichlids in a subtropical African river system (Limpopo River, South Africa). Environmental Biology of Fishes 92: 479-489. 